OPEN ACCESS

Edited by:

Thomas Algeo,

University of Cincinnati, United States

Reviewed by:

Michael Tuite,

NASA Jet Propulsion Laboratory

(JPL), United States

Aiguo Dong,

China University of Geosciences,

China

*Correspondence:

Tracy M. Quan

tracy.quan@okstate.edu

Specialty section:

This article was submitted to

Geochemistry,

a section of the journal

Frontiers in Earth Science

Received: 06 May 2021 Accepted: 02 August 2021

Published: 12 August 2021

Citation:

Quan TM and Adeboye OO (2021) Interpretation of Nitrogen Isotope

Profiles in Petroleum Systems:

A Review.

Front. Earth Sci. 9:705691. doi: 10.3389/feart.2021.705691

\section{Interpretation of Nitrogen Isotope Profiles in Petroleum Systems: A Review}

\author{
Tracy M. Quan* and Oyeleye O. Adeboye \\ Boone Pickens School of Geology, Oklahoma State University, Stillwater, OK, United States
}

Bulk sedimentary nitrogen isotope profiles are often used as proxies for depositional redox conditions, nitrogen cycling, and nutrient uptake in modern and ancient marine systems. The general preference in terms of analysis is that the sediments measured have undergone minimal thermal alteration, as post-depositional processes might have altered the initial $\delta^{15} \mathrm{~N}$ signal, thus complicating the interpretation of these records. Although not a traditional proxy for petroleum evaluation purposes, recently the use of nitrogen isotopes in petroleum systems has been investigated as potential proxies to reconstruct paleoenvironmental conditions such as redox, and for organic matter evaluation. In this paper we review the use of nitrogen isotope data in petroleum systems, their interpretations, and factors that may complicate their use as proxies. We review the evidence for nitrogen isotopic fractionation during diagenesis, catagenesis, and fluid migration as determined by lab experiments, and how these might impact interpretation of $\delta^{15} \mathrm{~N}$ data in petroleum systems. We also analyze the use and interpretation of $\delta^{15} \mathrm{~N}$ data from petroleum-producing reservoir units, including unconventional reservoirs and lacustrine basins. Lastly, we discuss potential applications for nitrogen isotopes in petroleum systems with regards to their use as both geochemical proxies and as tools to evaluate petroleum reservoirs.

Keywords: nitrogen isotopes, petroleum systems, diagenesis, redox, catagenesis, organic matter transformation

\section{INTRODUCTION}

Nitrogen isotopes are being used in an increasing number of recent sedimentary system studies as paleoenvironmental proxies. Nitrogen isotope $\left(\delta^{15} \mathrm{~N}\right)$ measurements of sediments have been shown to record processes occurring in the water column, allowing them to serve as proxies for paleoredox conditions and nitrogen cycling (Altabet and Francois, 1994). As a result, sedimentary $\delta^{15} \mathrm{~N}$ data have been used to investigate the causes of mass extinctions, the extent of ocean anoxic events, and changes in oxygen minimum zones on glacial-interglacial time scales (e.g., Ganeshram et al., 1995; Calvert et al., 2001; Jenkyns et al., 2001; Quan et al., 2008; Ryabenko et al., 2012). Sedimentary $\delta^{15} \mathrm{~N}$ profiles have also been used to identify intervals and locations where the nitrogen cycle and nutrient regimes appear to have been significantly altered from that for the modern-day, including Precambrian conditions and Mediterranean sapropel deposits (e.g., Godfrey and Falkowski, 2009; Higgins et al., 2010; Ader et al., 2016). These evaluations of paleoredox conditions and changes in the nitrogen cycle can provide critical evidence for the occurrence of larger biogeochemical cycle changes or geological events, 


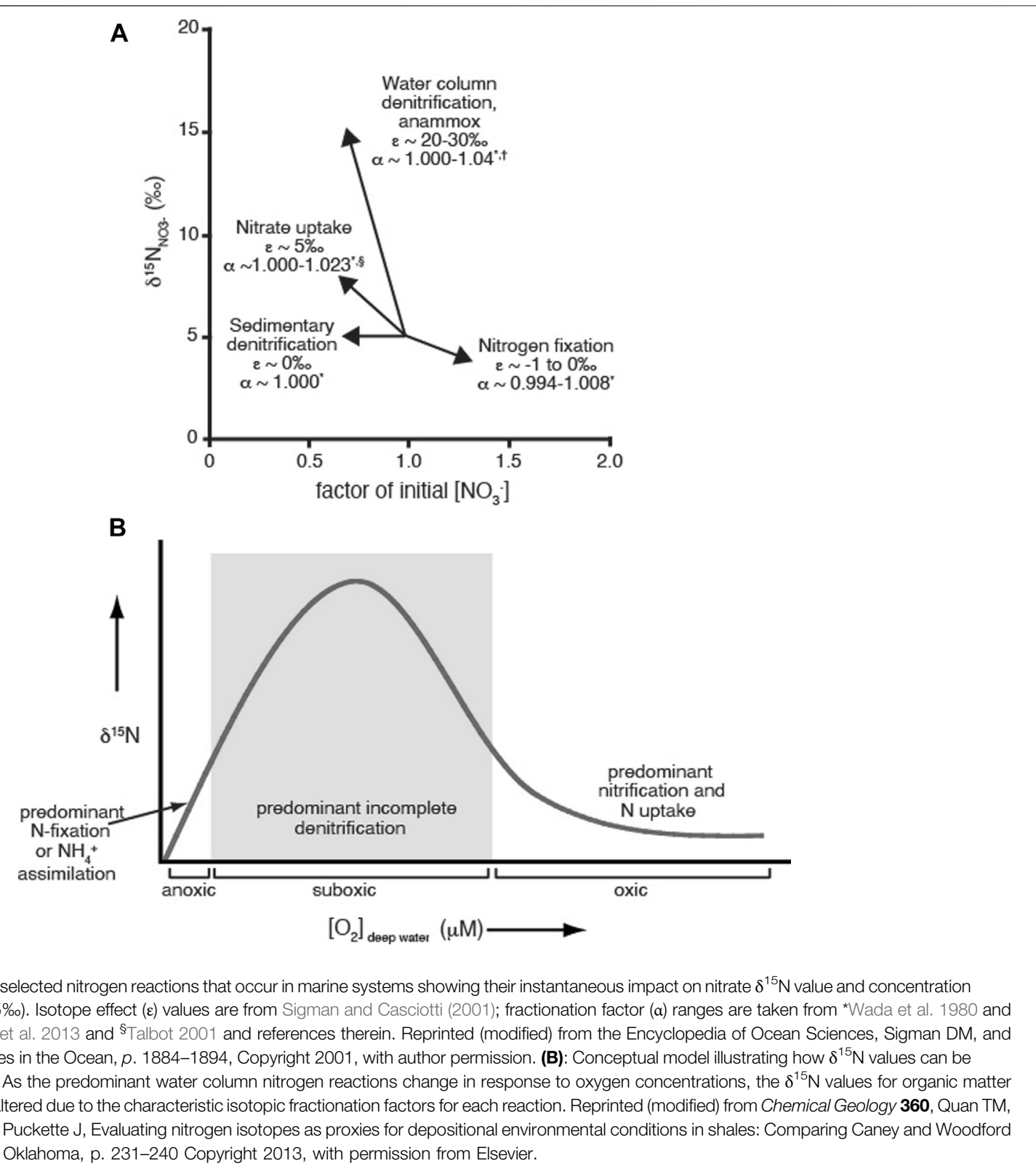

such as emplacement of large igneous provinces, climate change, changes in export production, or the timing of the Great Oxygenation Event (e.g., Holloway and Dahlgren, 2002; Meyers et al., 2009; Algeo et al., 2014; Ader et al., 2016; Danzelle et al., 2020).

Nitrogen is an essential bionutrient for all living creatures, and is a critical component of many biological compounds, including proteins, enzymes, and nucleic acids. Nitrogen can also be found in a range of oxidation states ranging from -III in $\mathrm{NH}_{3}$ and organic $\mathrm{N}$ compounds to $+\mathrm{V}$ in $\mathrm{NO}_{3}{ }^{-}$. Nitrogen has two isotopes: ${ }^{14} \mathrm{~N}(99.63 \%$ abundance $)$ and ${ }^{15} \mathrm{~N}(0.37 \%$ abundance); due to the much higher abundance of ${ }^{14} \mathrm{~N}$, measured isotopic values are reported as $\delta^{15} \mathrm{~N}$ in parts per thousand (per mil; \%o):

$$
\delta^{15} N=\left[\frac{\left({ }^{15} N /{ }^{14} N\right)_{\text {sample }}}{\left({ }^{15} N /{ }^{14} N\right)_{\text {standard }}}-1\right] \times 1000
$$

The reference standard is atmospheric nitrogen gas, set by definition to $\delta^{15} \mathrm{~N}=0 \%$. Measured samples that are depleted in ${ }^{15} \mathrm{~N}$ relative to the standard have negative $\delta^{15} \mathrm{~N}$ values, while samples that are relatively enriched in ${ }^{15} \mathrm{~N}$ have positive $\delta^{15} \mathrm{~N}$ values. Transformation of nitrogen between oxidation states and between organic and inorganic forms is predominantly mediated by organisms. Due to differences in bond strengths between ${ }^{14} \mathrm{~N}$ and ${ }^{15} \mathrm{~N}$, isotopic fractionation occurs during these reactions, and therefore nitrogen isotopes can be used to provide information about the reactions involved and the larger nitrogen cycle. The 
fractionation factor $(\alpha)$ for any reaction can be calculated as the difference in ${ }^{15} \mathrm{~N} /{ }^{14} \mathrm{~N}$ ratios between reactants $(\mathrm{R})$ and products $(\mathrm{P})$ :

$$
\alpha_{N_{R} \rightarrow N_{P}}=\frac{\left({ }^{15} N /{ }^{14} N\right)_{R}}{\left({ }^{15} N /{ }^{14} N\right)_{P}}
$$

If no fractionation takes place, $\alpha=1$; reactions that favor the light isotope have $\alpha>1$, and reactions that favor the heavier isotope have $\alpha<1$. Similarly, kinetic fractionation can be assessed using the kinetic isotope effect $(\varepsilon)$, which is the difference in rates of reaction for each isotope. For reactions taking place in natural systems, $\varepsilon$ is essentially the difference between the $\delta^{15} \mathrm{~N}$ value of the reactant and that of the instantaneous product formed. Figure 1A shows a schematic of isotope effects for nitrogen reactions that are important to the geologic aquatic nitrogen cycle, along with their associated fractionation factors $(\alpha)$ and isotope effects ( $\varepsilon$ ) (Delwiche and Steyn, 1970; Wada et al., 1980; Sigman and Casciotti, 2001; Talbot, 2001; Brunner et al., 2013). Measured fractionation factors for nitrogen processes may vary depending on the reaction pathway, culture or field measurement, and the specific species measured (Delwiche and Steyn, 1970; Wada et al., 1980 and references therein; Talbot, 2001 and references therein). If a reaction proceeds to completion, no fractionation is observed.

The interpretations of $\delta^{15} \mathrm{~N}$ data with regards to paleoredox conditions and nitrogen cycling rely on the fractionation factors for different nitrogen reactions (Figure 1A), which are in turn set by environmental conditions, particularly oxygen concentrations. The details have been discussed in several papers (e.g., Delwiche and Steyn, 1970; Wada et al., 1980; Altabet and Francois, 1994; Talbot, 2001; Robinson et al., 2012), but in brief, the sedimentary $\delta^{15} \mathrm{~N}$ values reflect the $\delta^{15} \mathrm{~N}$ of sinking organic matter, which is in turn influenced by the nitrogen reactions and environmental conditions occurring in the water column. In general, higher sedimentary $\delta^{15} \mathrm{~N}$ values are representative of low oxygen/ suboxic water column conditions, because these conditions favor strongly fractionating denitrification and anammox reactions that result in organic matter enriched in ${ }^{15} \mathrm{~N}$, which is recorded in the sediments as higher $\delta^{15} \mathrm{~N}$ values (Altabet and Francois, 1994; Robinson et al., 2012 and references within). Lower $\delta^{15} \mathrm{~N}$ values can represent either anoxic systems dominated by nitrogen fixation or ammonium assimilation, or oxic systems utilizing nitrate as the main source of nitrogen; the nitrogen reactions for both of these conditions have smaller fractionation factors, and therefore generate organic matter depleted in ${ }^{15} \mathrm{~N}$. The conceptual model of how sedimentary $\delta^{15} \mathrm{~N}$ values vary with oxygen levels is shown in Figure 1B. Since sedimentary $\delta^{15} \mathrm{~N}$ values represent the average of all nitrogen processes occurring in the water column at a particular location, nitrogen isotopes are a local proxy. Nitrogen isotope values in sedimentary systems also reflect the $\delta^{15} \mathrm{~N}$ values of the initial nitrate or ammonium used to produce the organic matter, so variations in the $\delta^{15} \mathrm{~N}$ record may reflect the input of different sources of nitrogen into the system (Altabet and Francois, 1994; Robinson et al., 2012 and references within). Therefore, correlating specific $\delta^{15} \mathrm{~N}$ values to exact $\mathrm{O}_{2}$ concentrations can be difficult, particularly for historical records.
One of the main concerns in the interpretation of sedimentary $\delta^{15} \mathrm{~N}$ records is whether the sedimentary $\delta^{15} \mathrm{~N}$ values measured accurately reflect the water column processes, or whether there is alteration of the record either during the initial organic matter sedimentation or through post-depositional processes. In brief, loss of nitrogen compounds could result in altering the original $\delta^{15} \mathrm{~N}$ signal through removal of compounds that are either enriched or depleted in ${ }^{15} \mathrm{~N}$ (Robinson et al., 2012 and references within). This could result in measured $\delta^{15} \mathrm{~N}$ values that do not correspond to the original environmental conditions and nitrogen reactions. Remineralization of nitrogen compounds is most likely to occur at locations at which the water column and sediments are predominantly oxic, sedimentation rates are particularly slow, or productivity is low, so use of nitrogen isotopes as proxies in these environments may not be straightforward. Isotopic alteration may also occur at the sediment-water interface, with some evidence for preferential loss of nitrogen compounds with lower $\delta^{15} \mathrm{~N}$ values, resulting in a shift to higher $\delta^{15} \mathrm{~N}$ values measured in the sediment (Freudenthal et al., 2001; Robinson et al., 2012 and references within). Other processes that may alter the initial $\delta^{15} \mathrm{~N}$ signal include input of $\mathrm{NH}_{4}{ }^{+}$or terrestrial nitrogen from outside sources into the sediments. These alterations to the bulk sedimentary $\delta^{15} \mathrm{~N}$ signal may be identified by isolating and measuring specific fractions that are more resistant to alteration such as compounds derived from chlorophyll, or that have been physically protected, such as microfossil bound compounds. Bulk sedimentary $\delta^{15} \mathrm{~N}$ measurements from areas where the organic matter is wellpreserved are generally considered to be accurate proxies of water-column processes, so measurements from suboxic to anoxic environments or high sedimentation rate locations can be used for reconstruction of paleoenvironmental conditions with a high degree of confidence. In order to conform to the tenets of Fretwell's Law (as cited by Kendall and Caldwell, 1998), which cautions against using stable isotope data as the sole source of information, other redox and environmental proxies, such as biomarkers, paleontological evidence, and element enrichment, should be used to provide additional support and context for interpretation of $\delta^{15} \mathrm{~N}$ data (e.g., Lee et al., 2019; Adeboye et al., 2020).

Given the caveats associated with interpretation of $\delta^{15} \mathrm{~N}$ profiles for modern and ancient sedimentary systems that have not undergone significant post-depositional alteration, the potential use of nitrogen isotopes as paleoenvironmental and nitrogen cycle proxies in petroleum systems deserves additional analysis. In this paper, we review the recent research on nitrogen isotopes in petroleum systems, including fractionation due to diagenesis and catagensis, and the influence of kerogen type, and highlight applications of $\delta^{15} \mathrm{~N}$ data as paleoenvironmental proxies in petroleum systems.

\section{POST-DEPOSITIONAL NITROGEN FRACTIONATION}

The reliability of proxies to be used to decipher paleoenvironmental conditions relies on the ability to identify 
TABLE 1 | List of previously published $\delta^{15} \mathrm{~N}$ values for a representative range of petroleum systems and petroleum-related samples.

\begin{tabular}{|c|c|c|c|c|}
\hline OM type & $\begin{array}{l}\text { Geographic } \\
\text { location }\end{array}$ & Formation & $\begin{array}{l}\text { Range of } \delta^{15} \mathrm{~N} \\
\text { values }\end{array}$ & Reporting reference(s) \\
\hline Bituminous sediment & Various & Various & +4.2 to $+10.7 \%$ & Stiehl and Lehmann (1980) \\
\hline Coal & Antarctica & Beaver Lake & $+3.0 \%$ & Rigby and Batts (1986) \\
\hline Coal & Australia & Various & +0.3 to $+3.7 \%$ & Rigby and Batts (1986) \\
\hline Coal & Canada & Various & -3.2 to $1.4 \%$ & Whiticar (1996) \\
\hline Coal & China & Various & -2.9 to $+3.6 \%$ & Ding et al. (2018) \\
\hline Coal & China & Huainan & +3.7 to $+7.7 \%$ & Xie et al. (2021) and references therein \\
\hline Coal & Various & Various & +3.5 to $+6.3 \%$ 。 & Stiehl and Lehmann (1980) \\
\hline Coal & Netherlands & State Mine Maurits & $+2 \%$ & Bokhoven and Theeuwen (1966) \\
\hline Coal & New Zealand & Stockton & $+1.3 \%$ & Rigby and Batts (1986) \\
\hline Coal after pyrolysis & Zwickau & & +3.9 to $5.1 \%$ & Stiehl and Lehmann (1980) \\
\hline Crude oil & China & Various & $\begin{array}{l}-5.79 \text { to } \\
+18.11 \%\end{array}$ & Chen et al. (2005) \\
\hline Crude oil & Japan & Various & +2.3 to $+5.1 \%$ & Wada et al. (1975) \\
\hline Crude oil & United States & Various & +1 to $+6.7 \%$ & Hoering and Moore (1958) \\
\hline $\begin{array}{l}\text { Neutral, low polarity oil } \\
\text { fraction }\end{array}$ & China & Liaohe Basin & +10.6 to $+12.2 \%$ & Oldenburg et al. (2007) \\
\hline $\begin{array}{l}\text { Neutral, high polarity oil } \\
\text { fraction }\end{array}$ & China & Liaohe Basin & +9.0 to $+11.3 \%$ & Oldenburg et al. (2007) \\
\hline Basic oil fraction & China & Liaohe Basin & +4.1 to $+5.8 \%$ & Oldenburg et al. (2007) \\
\hline Kerogen (undifferentiated) & Australia & Various & -2.25 to $+5.34 \%$ & Stüeken et al. (2017) and references therein \\
\hline Kerogen (undifferentiated) & Canada & Sulphur Mountain Formation & +2.92 to $+7.42 \%$ & Stüeken et al. (2017) and references therein \\
\hline Kerogen (undifferentiated) & China & Various & -0.48 to $+7.50 \%$ o & Chen et al. (2005) \\
\hline Kerogen (undifferentiated) & Mexico & Bandaras Bay & +2.4 to $+4.2 \%$ & Peters et al. (1978) \\
\hline Kerogen (undifferentiated) & South Africa & Witwatersrand Supergroup & -4.44 to $-0.48 \%$ o & Stüeken et al. (2017) and references therein \\
\hline Kerogen (undifferentiated) & Switzerland & Serpiano Oil Shale & $-0.9 \%$ & Chicarelli et al. (1993) \\
\hline Kerogen (undifferentiated) & Unite States & Various & -1.67 to $+9.9 \%$ & $\begin{array}{l}\text { Peters et al. (1978) and Stüeken et al. (2017) and references } \\
\text { therein; Williams et al. (1995) }\end{array}$ \\
\hline Type I Kerogen & Russia & Shungite & $+3.4 \%$ & Boudou et al. (2008) and references therein \\
\hline Type I Kerogen & United States & $\begin{array}{l}\text { Mahogany Shale, Green River } \\
\text { Formation }\end{array}$ & $+16.8 \%$ & Schimmelmann and Lis (2010) and references therein \\
\hline Type II Kerogen & United States & New Albany Shale & -1.3 to $+1.2 \%$ & $\begin{array}{l}\text { Boudou et al. (2008) and references therein; Schimmelmann and } \\
\text { Lis (2010) and references therein }\end{array}$ \\
\hline Type II-S Kerogen & Jordan & Sononian Ghareb limestone & $+9.0 \%$ & Schimmelmann and Lis (2010) and references therein \\
\hline Type III Kerogen & Various & Various & +2.2 to $+6.0 \%$ o & $\begin{array}{l}\text { Boudou et al. (2008) and references therein; Schimmelmann and } \\
\text { Lis (2010) and references therein }\end{array}$ \\
\hline Sapropelic kerogen & Mexico & Laguna Mormona Algal mats & +1.87 to $+6.18 \%$ o & Peters et al. (1981) \\
\hline Humic kerogen & United States & $\begin{array}{l}\text { Staten Island Peaty Soil } \\
\text { Kerogen }\end{array}$ & +1.15 to $+5.31 \%$ o & Peters et al. (1981) \\
\hline Mudstone & United States & Fordoche Field & +0.7 to $+4.5 \%$ & Williams et al. (1995) \\
\hline Natural gas & China & Yinggehai Basin & $-9.0 \%$ to $-1.8 \%$ o & Zhu et al. (2000) \\
\hline Natural gas & Germany & Mid-European Basin & +6.5 to $+18.0 \%$ & Zhu et al. (2000) and references therein \\
\hline Natural gas & Netherlands & Slochteren & +12 to $+18 \%$ o & Bokhoven and Theeuwen (1966) \\
\hline Natural gas & Poland & Zechstein Main Dolomite & +9.2 to $+15.9 \%$ & Kotarba et al. (2020) and references therein \\
\hline Natural gas & Russia & West Siberian Basin & -19.0 to $-10.7 \%$ & Zhu et al. (2000) and references therein \\
\hline Natural gas & United States & Various & -10.5 to $+14.4 \%$ & $\begin{array}{l}\text { Hoering and Moore (1958) and Zhu et al. (2000) and references } \\
\text { therein }\end{array}$ \\
\hline Oil shale & Australia & Various & -2.5 to $+12.7 \%$ & Rigby and Batts (1986) \\
\hline Organic extract & Poland & Various & -1.7 to $+1.8 \%$ o & Bauersachs et al. (2009) \\
\hline Organic extract & Switzerland & Serpiano oil Shale & $-3.97 \%$ & Chicarelli et al. (1993) \\
\hline Organic matter & Germany & Wealden shale & $\begin{array}{l}+10.11 \text { to } \\
+15.03 \%\end{array}$ & Froidl et al. (2021) \\
\hline Porphyrins & Switzerland & Serpiano oil Shale & -3.04 to $-3.38 \%$ & Chicarelli et al. (1993) \\
\hline Shale & Oklahoma & Caney & +8.2 to $+11.2 \%$ & Quan et al. (2013) \\
\hline Shale & Oklahoma & Woodford & +1.5 to $+9.5 \%$ & Quan et al. (2013) and Rivera et al. (2015) \\
\hline Shale & Virginia & Chattanooga & -0.7 to $3.0 \%$ & Tuite et al. (2019) \\
\hline
\end{tabular}

For analytical and sample details, please refer to the original articles. Please note that this is not an exhaustive list of all published $\delta^{15} \mathrm{~N}$ values from petroleum-focused nitrogen isotope studies.

and constrain the relationship between the measured proxy and the parameter it represents. In the case of bulk sedimentary $\delta^{15} \mathrm{~N}$ profiles in petroleum systems, this means trying to characterize any deviations from the initial $\delta^{15} \mathrm{~N}$ value set by nitrogen reactions in response to paleoenvironmental conditions during deposition to those measured in the bulk sediment from core samples and outcrops. Since the organic matter has undergone significant transformation from fresh organic matter to 


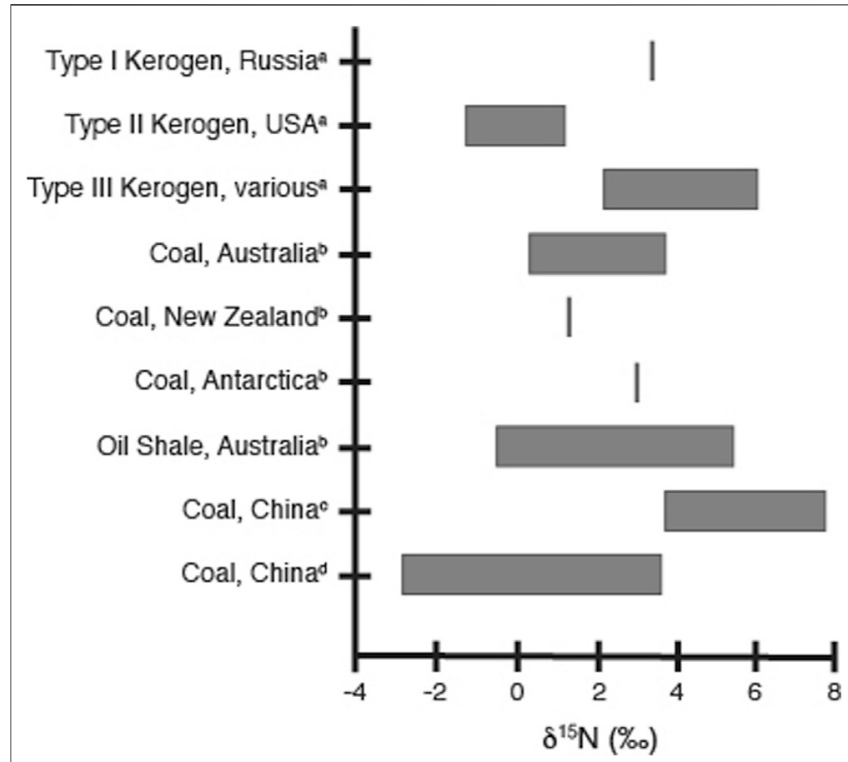

FIGURE 2 | Ranges of measured $\delta^{15} \mathrm{~N}$ values for selected kerogen and coal samples, as referred to in the text. Values shown are from ${ }^{\mathrm{a} B o u d o u}$ et al. 2008 and references therein, bigiby and Batts 1986, ' $X i e$ et al. 2021 and references therein, and ${ }^{\mathrm{d} D i n g}$ et al. 2018; for analytical and sample details, please refer to the original articles.

petroleum, it is likely that the nitrogen isotope values have also been altered by these same processes. Unfortunately, identification and quantification of these transformation processes and the nitrogen isotope fractionation factors associated with them are not easy to determine or constrain. The heterogeneity of organic matter, the difficulty in characterizing elemental and compositional changes during diagenesis and catagenesis, and the limitations of laboratory pyrolysis experiments are all issues that complicate interpretation of experimental and field measurements of nitrogen isotope fractionation. As a result, there are a limited number of studies and a limited number of sample types in the literature. While we have listed some representative $\delta^{15} \mathrm{~N}$ values for a range of petroleum systems and petroleum-related samples (Table 1), it should be clear upon inspection that there are no universal $\delta^{15} \mathrm{~N}$ values or trends that characterize samples from petroleum systems. As with any interpretation of stable isotope data, the geological and geochemical context of particular samples are critical to understanding what processes might be represented by the $\delta^{15} \mathrm{~N}$ values.

In theory, alteration of the original water column $\delta^{15} \mathrm{~N}$ signal in petroleum systems can result via four possible pathways: inclusion of other organic matter compounds from alternate sources in the organic matter pool; alteration of the initial $\delta^{15} \mathrm{~N}$ signal during sedimentary diagenesis; alteration of the initial $\delta^{15} \mathrm{~N}$ signal during catagensis; and overprinting of the initial $\delta^{15} \mathrm{~N}$ signal through interaction with, or migration of, nitrogen-containing fluids. Each of these pathways has the potential to lead to misinterpretation of the initial environmental conditions and thus an inability to use bulk sedimentary nitrogen isotopes as a paleoredox proxy in petroleum systems.

\section{Kerogen Type}

In order for the bulk sedimentary $\delta^{15} \mathrm{~N}$ profiles to accurately represent paleoenvironmental conditions, the nitrogen measured should have originated from biological processes occurring in the water column, and not from outside sources. This would imply that petroleum systems containing kerogen with a large marine algal and phytoplankton input (Type I and Type II kerogen) would be more likely to reflect environmental water column nitrogen reactions than kerogen with a high terrestrial input (Type III kerogen). In addition to not reflecting water column processes, nitrogen isotope values of terrestrial organic material are often more variant and have a wider range of values than those from marine systems (Kendall, 1998 and references within). The influence of terrestrial input on the sedimentary organic matter can be traced through the $\mathrm{C} / \mathrm{N}$ ratio, as terrestrial materials generally have a higher ratio than those of marine phytoplankton (Hedges and Mann, 1979). This is reflected in higher $\mathrm{N}_{\text {org }} / \mathrm{C}_{\text {org }}$ ratios for Type II kerogen compared to Type III kerogen at comparable maturities even after nitrogen is lost preferentially to carbon during diagenesis (Boudou et al., 2008). This difference in source is reflected in the measured $\delta^{15} \mathrm{~N}$ values, with $\delta^{15} \mathrm{~N}$ values for Type II kerogen generally similar to that measured in black shale samples $(\sim-2$ to $+2 \%$ ), and the $\delta^{15} \mathrm{~N}$ values for Type III kerogen closely resembling those for coal $(\sim+2$ to $+6 \%)$ (Figure 2; Boudou et al., 2008). Similarly, the $\delta^{15} \mathrm{~N}$ values $\mathrm{x}$ for coals and lacustrine and brackish-water oil shales are generally higher than for oil shales deposited under marine conditions, reflecting both organic matter source and the nitrogen utilization of the precursor organisms (Rigby and Batts, 1986). The $\delta^{15} \mathrm{~N}$ values of coals, in particular, reflect the organic matter source and composition rather than maturity or diagenesis (Figure 2; Rigby and Batts, 1986; Ding et al., 2018; Xie et al., 2021). These distinctions between the marine and terrestrial organic matter sources indicates that if the nitrogen source or kerogen type is unknown, caution must be used when interpreting $\delta^{15} \mathrm{~N}$ records in petroleum systems, as higher $\delta^{15} \mathrm{~N}$ values could be a consequence of suboxic conditions characterized by predominant water column denitrification or reflect the presence of significant amounts of terrestrial input. While this is also true of all sedimentary systems, the transformation of the initial organic material during diagenesis and catagenesis may make identification of terrestrial input through $\mathrm{C} / \mathrm{N}$ ratios more difficult.

\section{Diagenesis}

The loss of organic nitrogen during diagenesis and catagenesis is well documented (e.g., Tissot and Welte, 1984; Prokopenko et al., 2006 and references within; Vandenbrouke and Largeau, 2007); however, how these processes alter the $\delta^{15} \mathrm{~N}$ signal in bulk sediment is not conclusive. Figure 3 summarizes four different possible scenarios for the relationship between the N/C ratio of kerogen and the $\delta^{15} \mathrm{~N}_{\text {kerogen }}$ in sediments. As stated earlier, analysis of modern-day core top and particulate organic 


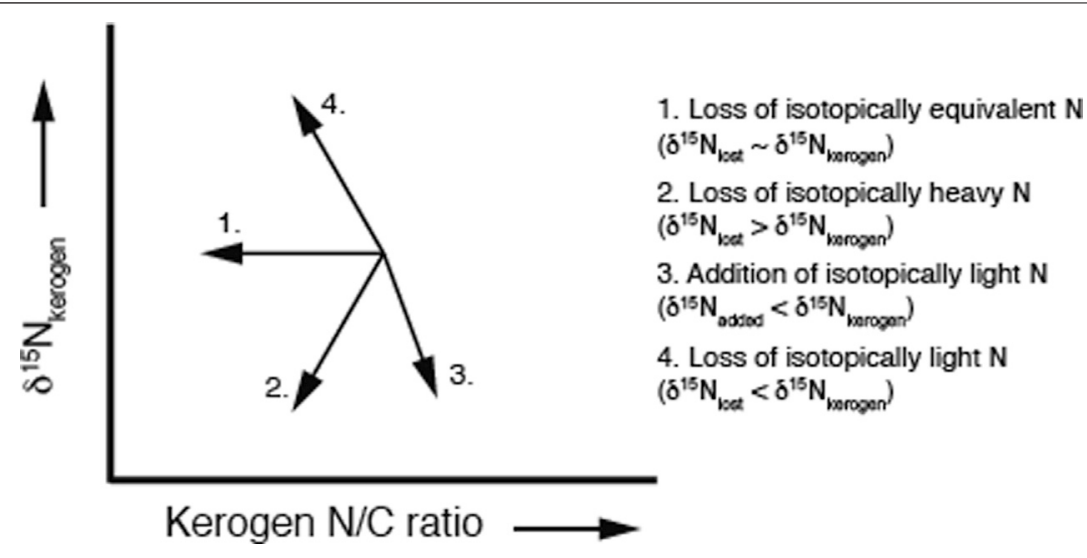

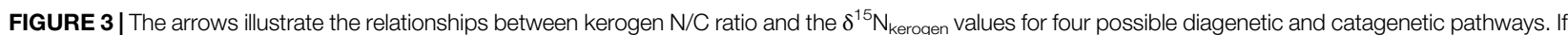
nitrogen is lost that has a similar $\delta^{15} \mathrm{~N}$ value as the original kerogen, the $\mathrm{N} / \mathrm{C}$ ratio will decrease without changing the $\delta^{15} \mathrm{~N}_{\text {kerogen }}$ (arrow 1 ). Loss of isotopically heavy $\mathrm{N}$ will result in decreasing values for both $\mathrm{N} / \mathrm{C}$ ratio and $\delta^{15} \mathrm{~N}_{\text {kerogen }}$ (arrow 2). If diagenetic/catagenic processes result in the addition of $\mathrm{N}$ compounds that are isotopically light, $\delta^{15} \mathrm{~N}_{\text {kerogen }}$ will decrease while the $\mathrm{N} / \mathrm{C}$ ratio increases (arrow 3). Removal of $\mathrm{N}$ compounds that have low $\delta^{15} \mathrm{~N}$ values from the kerogen will show an increase in $\delta^{15} \mathrm{~N}_{\text {kerogen }}$ values and a decrease in $\mathrm{N} / \mathrm{C}$ ratio.

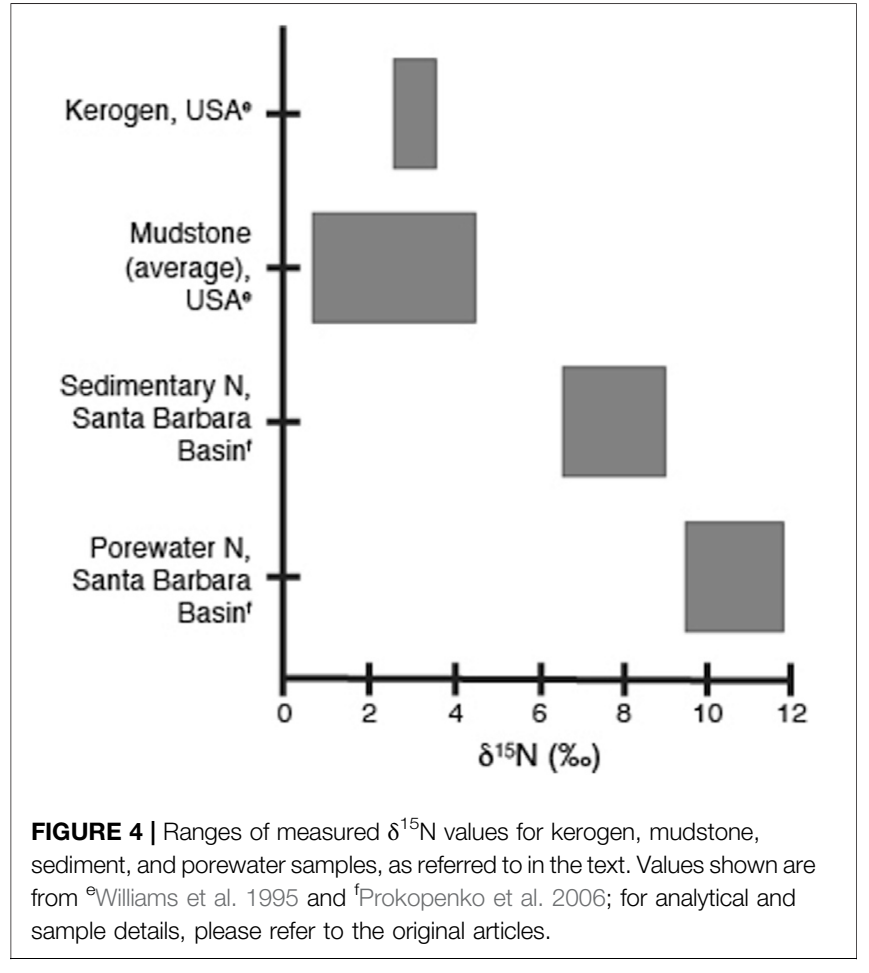

matter indicates that in general, sedimentary $\delta^{15} \mathrm{~N}$ is an accurate recorder of water column processes, even when degradation has occurred (Peters et al., 1978; Altabet and Francois, 1994; Robinson et al., 2012 and references within). During diagenesis, organic nitrogen is converted to ammonium $\left(\mathrm{NH}_{4}{ }^{+}\right)$which can be trapped in the sediments, particularly in clay minerals. Detailed analysis of the nitrogen isotope values for the ammonium released provides conflicting information regarding fractionation during diagenesis. One scenario argues that since the $\mathrm{NH}_{4}{ }^{+}$is generated from the organic nitrogen pool, the isotopic values are thought to be similar to the originating organic matter (Scholten 1991; Williams et al., 1995; Hoefs, 2004). Williams et al. (1995) compared the $\delta^{15} \mathrm{~N}$ values of clay-fixed $\mathrm{NH}_{4}{ }^{+}$from mudstones with the $\delta^{15} \mathrm{~N}$ values of the associated kerogen and found no significant difference, leading them to conclude that the mudstones must be acting as a closed system (Figure 4). In this scenario, the $\delta^{15} \mathrm{~N}$ profile of the remaining sedimentary organic matter would be unchanged despite the loss of $\mathrm{N}$ as illustrated by arrow 1 in Figure 3, and thus primarily reflect processes that set the $\delta^{15} \mathrm{~N}$ values of the initial organic matter and not fractionation during diagenesis.

An alternative scenario is that nitrogen isotope fractionation does occur during the generation of $\mathrm{NH}_{4}{ }^{+}$, with the degree and direction of fractionation varying with environmental conditions during diagenesis. Incubation experiments under anoxic conditions show a decrease in the $\delta^{15} \mathrm{~N}$ values of organic matter of approximately $3 \%$ due to microbial degradation (Lehmann et al., 2002). Similarly, analysis of $\delta^{15} \mathrm{~N}^{-\mathrm{NH}_{4}}{ }^{+}$in pore water in the modern-day Santa Barbara Basin shows an enrichment of $1-3 \%$ compared to the residual organic matter (Prokopenko et al., 2006). Anoxic degradation appears to result in either the loss of a pool of organic nitrogen that is ${ }^{15} \mathrm{~N}$-enriched (Figure 3, arrow 2), or the addition of a ${ }^{15} \mathrm{~N}$-depleted fraction to the organic matter pool (Figure 3, arrow 3). Generation of heavy $\mathrm{NH}_{4}{ }^{+}$via organic matter degradation could be due to anoxic diagenesis of more labile, isotopically enriched marine organic matter over more refractory, more depleted terrestrial nitrogen (Prokopenko et al., 2006). Incorporation of organic compounds generated by bacteria could be the source of lighter $\mathrm{N}$ to the organic matter pool (Lehmann et al., 2002). Unlike the incubation experiments, the loss of heavy nitrogen via diagenesis did not significantly change the $\delta^{15} \mathrm{~N}$ values of the sedimentary organic matter in the Santa Barbara Basin, likely due to sediment conditions favorable for good organic matter preservation (Figure 4; Prokopenko et al., 2006). It is probable that the 
$\delta^{15} \mathrm{~N}$ values of organic matter could decrease during diagenesis if sediments had lower organic matter concentrations, slower sedimentation rates, and more oxic conditions, or in settings where the input of lower $\delta^{15} \mathrm{~N}$ compounds is significant. In contrast, oxic degradation increases the $\delta^{15} \mathrm{~N}$ value of organic matter (Figure 3, arrow 4) as ${ }^{15} \mathrm{~N}$-depleted nitrogen is preferentially lost as $\mathrm{NH}_{4}{ }^{+}$during early diagenesis (Macko and Estep, 1984; Holmes et al., 1999; Freudenthal et al., 2001; Lehmann et al., 2002). The bulk sedimentary $\delta^{15} \mathrm{~N}$ signal appears to reflect the $\delta^{15} \mathrm{~N}$ values of organic matter and thus reflect water column processes in organic-rich areas with rapid accumulation rates. In contrast, sediments with low organic $\mathrm{N}$ concentrations and high $\mathrm{NH}_{4}{ }^{+}$levels are more likely to have altered $\delta^{15} \mathrm{~N}$ profiles (Robinson et al., 2012 and references within). In a petroleum-generating system characterized by high organic matter concentrations and suboxic to anoxic environmental conditions, the use of $\delta^{15} \mathrm{~N}$ values as a redox proxy may be plausible. Plotting total organic carbon (TOC) concentrations vs total nitrogen (TN) concentrations for bulk sediment samples can provide information about excess inorganic $\mathrm{N}$ which may indicate whether significant diagenesis has occurred and that the $\delta^{15} \mathrm{~N}$ values for the bulk sediment may have been altered (Calvert, 2004).

\section{Catagenesis}

Even after diagenesis, there is still nitrogen present in kerogen that can be lost during catagenesis, potentially resulting in additional nitrogen isotope fractionation. While modern-day systems can be used to evaluate alteration of $\delta^{15} \mathrm{~N}$ values during diagenesis, no such analogs exist for catagenesis. Changes in the nitrogen content and isotopic values due to catagenesis can only be evaluated through laboratory experiments or inferred through analysis of sediments from petroleum reservoirs. Though these analyses are imperfect due to the limitations of pyrolysis/thermal maturity experiments and the difficulty in isolating catagenic effects from other geological processes in petroleum-generating systems, all studies indicate that nitrogen is lost during catagenesis. Analysis of kerogen isolated from sediments after a series of thermal maturation experiments indicates that changes in nitrogen content with temperature were complex and varied with organic matter type, as algal-rich sediments showed a different pattern compared to more terrestrial peat-rich sediments (Peters et al., 1981). The amount of nitrogen lost during catagenesis also appeared to vary by kerogen maturity and on the method of evaluation. Analysis of nitrogen loss using pyrolysis results in low release of nitrogen from both Type I and Type II kerogen, generally less than $12 \%$ of the initial kerogen $\mathrm{N}$ concentration (Barth et al., 1996; Gillaizeau et al., 1997; Behar et al., 2000). In comparison, evaluation of $\mathrm{C} / \mathrm{N}$ ratios and total $\mathrm{N}$, organic $\mathrm{N}$, and fixed- $\mathrm{NH}_{4}{ }^{+}$concentrations of samples from both oil-producing and non-productive areas of the Santa Maria and San Joaquin Basins in California indicates that about half the nitrogen remaining after diagenesis is lost (Compton et al., 1992). Some of this difference may be due to a discrepancy in the inorganic $\mathrm{N}$ that is measured in the field versus what is measured in pyrolysis studies. The pyrolysis experiments found that the majority of the

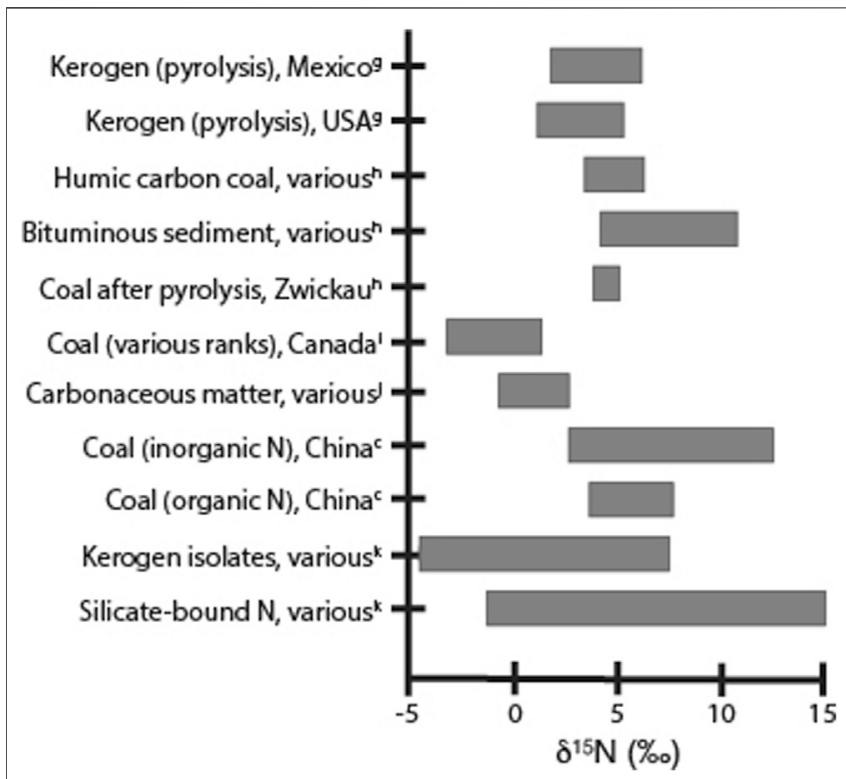

FIGURE 5 | Ranges of measured $\delta^{15} \mathrm{~N}$ values for kerogen, coal, and silicate-bound nitrogen samples, as referred to in the text. Values shown are from 9Peters et al. 1981, ' 'Stiehl and Lehmann 1980; 'Whiticar 1996, 'ंAder et al. 2006, 'Xie et al. 2021, and ' Stüeken et al. 2017; for analytical and sample details, please refer to the original articles.

$\mathrm{N}$ released from kerogen was as $\mathrm{N}_{2}$ gas, with little as $\mathrm{NH}_{3}$ (Gillaizeau et al., 1997; Behar et al., 2000). In contrast, the field analyses generally measured $\mathrm{NH}_{4}{ }^{+}$in the surrounding matrix, which could possibly have been brought in from outside the system, though $\mathrm{C} / \mathrm{N}$ ratios document significant $\mathrm{N}$ loss (Compton et al., 1992). Field analyses in natural gas systems have measured $\mathrm{N}_{2}$ levels, but it is unclear how much of the original kerogen-bound nitrogen was converted to gas (Zhu et al., 2000). Studies generally agree, however, that there is some amount of nitrogen in kerogen that is resistant to catagenic degradation, and that the majority of the nitrogen loss that does occur takes place at higher thermal maturities, with maximum $\mathrm{NH}_{4}{ }^{+}$evolution in the peak oil generation stage and maximum $\mathrm{N}_{2}$ release during gas generation (Compton, et al., 1992; Krooss et al., 1995; Littke et al., 1995; Barth et al., 1996; Gillaizeau et al., 1997; Behar et al., 2000). The degree and direction of nitrogen isotope fractionation that results from nitrogen loss during catagenesis is also highly variable (Figure 5). Some studies have found that increasing thermal maturity generally results in heavier $\delta^{15} \mathrm{~N}$ values for the remaining nitrogen in kerogen, since the light $\mathrm{N}$ is preferentially removed (Figure 5; Stiehl and Lehmann, 1980; Peters et al., 1981). In contrast, other evidence suggests that the $\delta^{15} \mathrm{~N}$ values for Type III kerogen and coals do not seem to change significantly with higher maturity levels even as $\mathrm{N}_{\text {org }}$ is lost, though the data for Type I and Type II kerogen is limited and inconclusive (Figure 5; Boudou et al., 1984; Rigby and Batts, 1986; Whiticar, 1996; Ader et al., 1998; Ader et al., 2006; Boudou et al., 2008; Xie et al., 2021). In other experiments, $\delta^{15} \mathrm{~N}_{\text {kerogen }}$ 
values decrease with increasing metamorphic grade, while the silicate-bound nitrogen becomes correspondingly heavier (Figure 5; Stüeken et al., 2017 and references within).

\section{Fluid Migration}

An additional difficulty in interpreting bulk $\delta^{15} \mathrm{~N}$ values in samples from petroleum systems is that these systems may experience nitrogen fractionation as a result of fluid interactions during migration, in addition to changes driven by diagenesis and catagenesis. Interaction with various fluids (e.g., during petroleum expulsion from source intervals, interaction with other nonpetroleum fluids in reservoir intervals) can result in nitrogen exchange between kerogen and nitrogen compounds in fluids, which can alter the $\delta^{15} \mathrm{~N}$ values of kerogen depending on the source and type of $\mathrm{N}$ compounds present in the fluids (Schimmelmann and Lis, 2010). Exchange within a basin may have the effect of homogenizing the $\delta^{15} \mathrm{~N}$ values for different $\mathrm{N}$ pools and in different areas across the basin, eliminating any variations in $\delta^{15} \mathrm{~N}$ values that may be diagnostic of prior geochemical processes or original paleoenvironmental conditions (Schimmelmann and Lis, 2010). Isotopic analysis of $\mathrm{NH}_{4}{ }^{+}$or $\mathrm{N}_{2}$ generated by diagenesis and catagensis may also be impacted by infiltration of those compounds from other sources or subsequent reaction in the fluid phase (e.g., Williams et al., 1995; Zhu et al., 2000; Xie et al., 2021). In particular, loss of light nitrogen either as $\mathrm{NH}_{3}$ (from the volatilisation of $\mathrm{NH}_{4}^{+}$) or $\mathrm{N}_{2}$ gas would result in enrichment for the remaining nitrogen in fluids (Williams et al., 1995; Ader et al., 1998; Krooss et al., 2005). Trapping of this heavy fluid nitrogen by clays could lead to higher $\delta^{15} \mathrm{~N}$ values for the bulk sediment in areas with significant concentrations of clay minerals (Charlesworth, 1986; Williams et al., 1995; Xie et al., 2021). The bulk sedimentary $\delta^{15} \mathrm{~N}$ values of petroleum reservoir sediments may also be influenced by the enrichment of the $\delta^{15} \mathrm{~N}$ values of organic nitrogen in petroleum due to migration (Williams et al., 1995 and references within).

\section{Impact on Interpretation of $\delta^{15} \mathrm{~N}$ Data}

Based on the previous paragraphs, it is clear that there is no consensus regarding the impact of kerogen type, diagenesis, catagenesis, fluid interaction, and migration on bulk sedimentary $\delta^{15} \mathrm{~N}$ values from petroleum systems. The heterogeneity of the organic matter, environmental conditions, and geological processes in petroleum systems make it complicated to interpret whether observed trends in bulk $\delta^{15} \mathrm{~N}$ values reflect initial nitrogen reactions and paleoredox conditions or if these trends indicate alteration (Table 1). If some broad conclusions can be drawn, the reliability of bulk sedimentary $\delta^{15} \mathrm{~N}$ records as redox proxies are higher if conditions are more conducive for organic matter preservation: high organic matter productivity, predominantly anoxic conditions, lower maturity, and minimal fluid interaction and migration.

Given all of the possible scenarios, it seems unlikely that the numerical value of bulk sedimentary $\delta^{15} \mathrm{~N}$ from petroleum systems is the same as the initial numerical value set during sediment deposition; however, it is possible that the relative relationships of $\delta^{15} \mathrm{~N}$ values within a sedimentary unit or location could be unchanged if the unit or location were subjected to similar geological processes over the interval in question. For example, this means that the presence of anoxic conditions could not be diagnosed based on a $\delta^{15} \mathrm{~N}$ value near $0 \%$, but an interval of lower $\delta^{15} \mathrm{~N}$ values within a profile of higher $\delta^{15} \mathrm{~N}$ values could be interpreted as an anoxic interval, particularly if supported by other geochemical and stratigraphic proxies. This means that it would be difficult to make direct comparisons of $\delta^{15} \mathrm{~N}$ values from sequences or locations that are too distant in either time or place, since they would likely be altered by different geological processes and therefore experience different influences with regards to isotopic fractionation. While there does seem to be some variation in sedimentary $\delta^{15} \mathrm{~N}$ values from unaltered systems through time on a global scale (Algeo et al., 2014), the potential fractionation due to catagenesis and migration likely make it inadvisable to draw global-scale conclusions from $\delta^{15} \mathrm{~N}$ measurements in petroleum systems.

\section{NITROGEN ISOTOPE MEASUREMENT}

Another potential complication in the comparison between $\delta^{15} \mathrm{~N}$ values for different locations and time periods is that the $\delta^{15} \mathrm{~N}$ values may also vary depending on the sediment fraction that is measured. The development of simpler and more sensitive isotope ratio mass spectrometer (IRMS) instrumentation in the last few decades means that the $\delta^{15} \mathrm{~N}$ of various nitrogen fractions can be measured relatively easily and using smaller sample sizes than in the past. The most basic measurement is bulk sedimentary $\delta^{15} \mathrm{~N}$, as the sediment samples simply need to be powdered, dried, and wrapped in tin capsules prior to combustion and analysis in an elemental analyzer (EA)-IRMS system, an improvement over the off-line Kjeldahl digestion or thermal oxidation methods previously used. This bulk sediment measurement can be referred to as $\delta^{15} \mathrm{~N}_{\text {bulk }}$, $\delta^{15} \mathrm{~N}_{\text {sed }}$, or $\delta^{15} \mathrm{~N}_{\mathrm{TN}}$, and represents the $\delta^{15} \mathrm{~N}$ of the total nitrogen in the sediments, a sum of both the organic material and any inorganic $\mathrm{N}$ trapped in mineral matrices. This has become the most common measurement used for the $\delta^{15} \mathrm{~N}$ redox proxy and is generally thought to accurately represent the original $\delta^{15} \mathrm{~N}$ of organic matter in the water column as any $\mathrm{NH}_{4}{ }^{+}$generated from the remineralization of organic matter is retained in the surrounding mineral matrix and included in the bulk measurement (Altabet and Francois, 1994; Higgins et al., 2012; Robinson et al., 2012).

In some samples, low organic matter concentrations or high amounts of detrital material may mean that nitrogen concentrations in the bulk sediments may be too low or too diluted to meet the detection limit of the IRMS. If the sediment is carbonate-rich, acidification methods can be used to reduce the sediment mass and concentrate the nitrogen. Acidification can either be performed in centrifuge tubes, with the residual sediments rinsed with water to remove acid then dried before analysis (rinse method), or on a smaller scale directly in silver capsules with the acid removed by evaporation (capsule method) (Brodie et al., 2011). The measured values for $\delta^{15} \mathrm{~N}_{\text {acidified }}$ are generally not the same as for $\delta^{15} \mathrm{~N}_{\text {bulk }}$ and the rinse method and the capsule method often return different $\delta^{15} \mathrm{~N}$ values. This 


\section{A Unconventional Reservoirs}

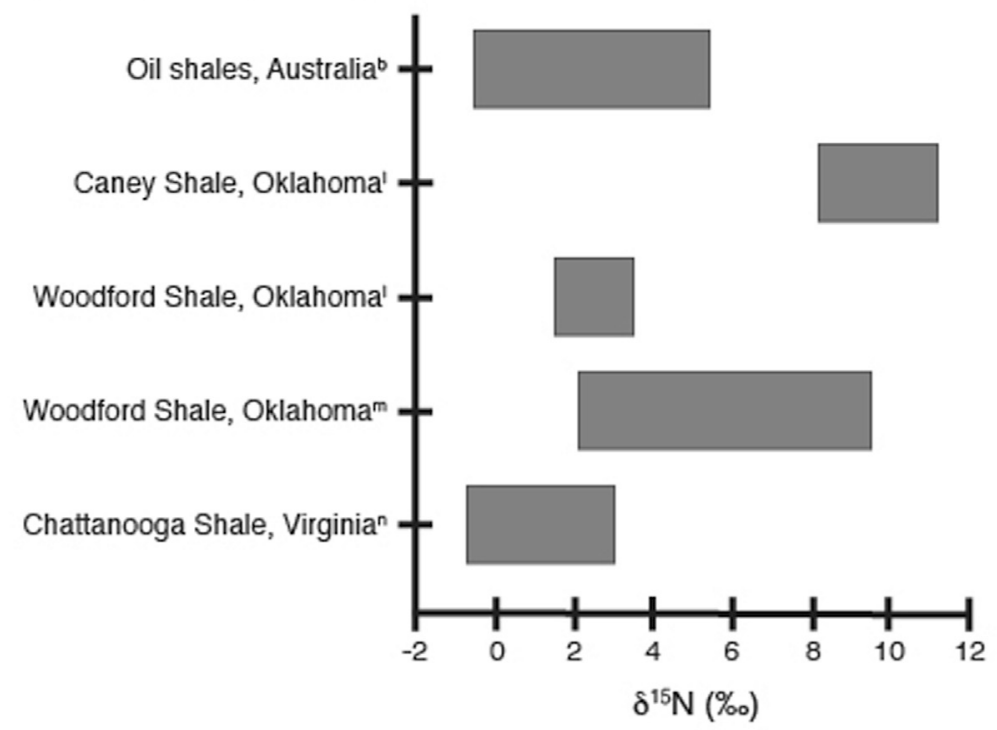

B Lacustrine Basins

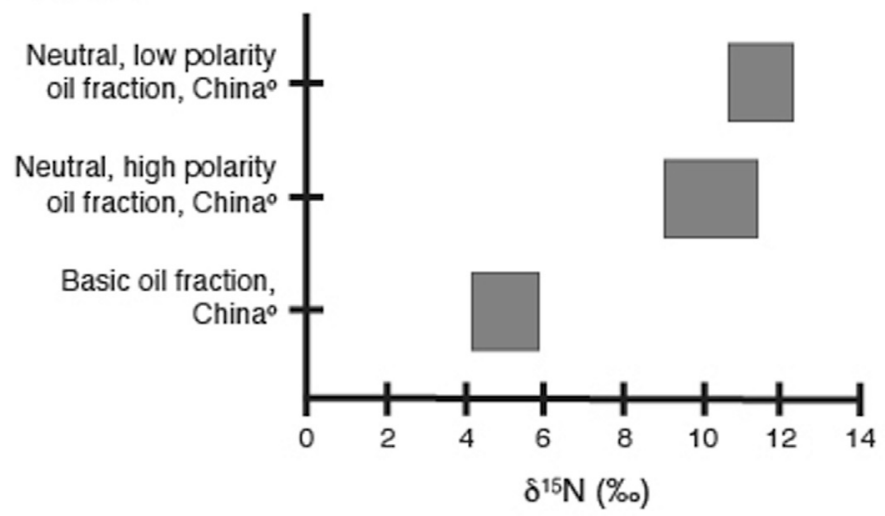

\section{Porphyrins}

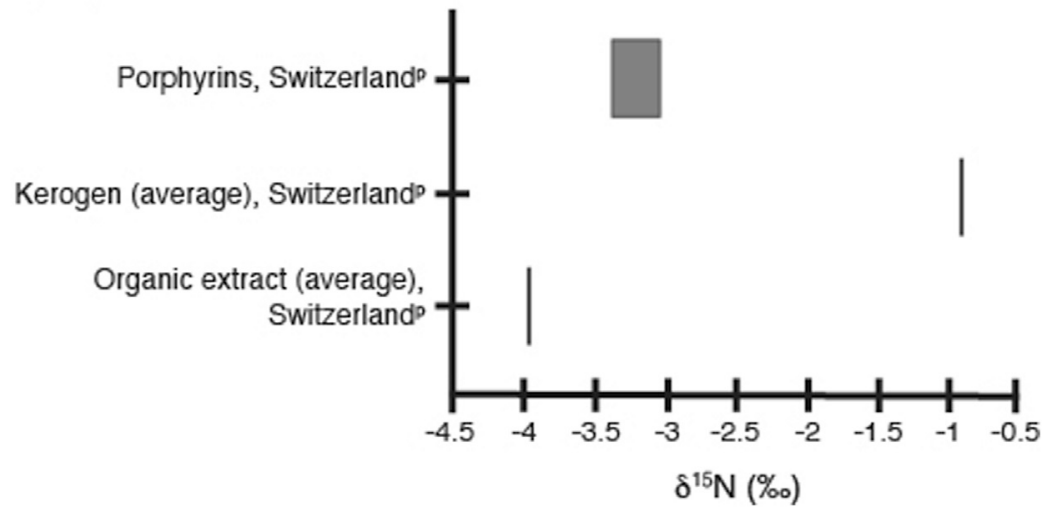

FIGURE 6 | (A): Ranges of measured $\delta^{15} \mathrm{~N}$ values for shale samples from unconventional reservoirs as referred to in the text. Values shown are from ${ }^{\mathrm{b}}$ Rigby and

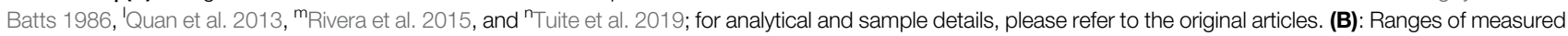
$\delta^{15} \mathrm{~N}$ values for lacustrine nitrogen fractions as referred to in the text. Values shown are from ${ }^{\circ}$ Oldenburg et al. 2007; for analytical and sample details, please refer to the original article. (C): Ranges of measured $\delta^{15} \mathrm{~N}$ values for porphyrin, kerogen, and organic extracts as referred to in the text. Values shown are from ${ }^{\mathrm{P} C h i c a r e l l i}$ et al. 1993; for analytical and sample details, please refer to the original article. 
indicates that some nitrogen is lost during the acidification process, possibly through loss of volatile nitrogen or watersoluble nitrogen, though the exact identity of the lost nitrogen fraction is still undetermined (Brodie et al., 2011). Therefore, the $\delta^{15} \mathrm{~N}_{\text {bulk }}$ and $\delta^{15} \mathrm{~N}_{\text {acidified fractions are not equivalent, and }}$ numerical comparison of these values should be done with caution.

Nitrogen isotope measurements of the isolated kerogen fraction can capture the organic $\mathrm{N}$ isotope signal without the interference of inorganic nitrogen compounds. This $\delta^{15} \mathrm{~N}_{\text {kerogen }}$ can be measured using solvent-extracted rock powder or on the kerogen obtained after removal of carbonate minerals by acidification and silicate minerals by HF (e.g., Higgins et al., 2012; Stüeken et al., 2017). Other nitrogen fractions can also be measured for $\delta^{15} \mathrm{~N}$, including silicate-bound, foram-bound, inorganic, porphyrins, polar $\mathrm{N}$ compounds, and neutral $\mathrm{N}$ compounds, if they can be isolated from the bulk sediment. As each of these fractions measures specific nitrogen fractions, comparison between the various $\delta^{15} \mathrm{~N}$ values may provide additional information regarding the partitioning of nitrogen and nitrogen isotopes between these pools (e.g., Oldenburg et al., 2007; Stüeken et al., 2017).

\section{INTERPRETATION OF $\delta^{15} \mathrm{~N}$ VALUES IN PETROLEUM SYSTEMS}

The use of sedimentary nitrogen isotopes in the evaluation of petroleum reservoirs has increased in recent years as the use of $\delta^{15} \mathrm{~N}_{\text {bulk }}$ as a redox proxy has become more established. While there is still much more work to be done on the theory and systematics of nitrogen isotope partitioning and fractionation in such systems, $\delta^{15} \mathrm{~N}$ values of various fractions can still be used to interpret depositional paleoenvironmental conditions, nitrogen cycling, and organic matter sources. Here we present some examples to illustrate how sedimentary $\delta^{15} \mathrm{~N}$ has been used in a range of petroleum systems to evaluate paleoredox conditions, lacustrine settings, and organic matter fractions.

\section{Unconventional Reservoirs}

Unconventional reservoirs are petroleum systems characterized by low porosity and permeability, which often results in a lack of a clear density separation for the hydrocarbons and formation fluids contained within the reservoir unit (J. Puckette, personal communication). A significant amount of research has been done over the last couple of decades into the systematics, depositional conditions, and reservoir characteristics of these organic-rich shale, mudstone, and carbonate deposits. Due to their low permeability and porosity, the $\delta^{15} \mathrm{~N}_{\text {bulk values from }}$ unconventional reservoirs are likely to retain the isotopic fingerprint of water column nitrogen sources and processes during deposition, as these systems would experience minimal migration of either the organic or inorganic nitrogen pools. Rigby and Batts (1986) measured the $\delta^{15} \mathrm{~N}$ of oil shale samples from Australia and noted that the $\delta^{15} \mathrm{~N}_{\text {bulk }}$ values reflected the type of organic material, nitrogen source, and paleoenvironmental conditions during deposition, similar to unaltered sediments (Figure 6A). To evaluate whether $\delta^{15} \mathrm{~N}$ profiles could be used as a paleoproxy for water column redox state, the $\delta^{15} \mathrm{~N}_{\text {bulk }}$ values for two productive units from Oklahoma with similar geological histories but different depositional redox conditions were compared. The $\delta^{15} \mathrm{~N}_{\text {bulk }}$ values from the Woodford Shale, deposited under anoxic conditions, were found to be lower than those from the overlying suboxic Caney Shale, supporting the interpretation that $\delta^{15} \mathrm{~N}_{\text {bulk }}$ profiles can be used as a paleoredox proxy even for oil-mature unconventional formations (Figure 6A; Quan et al., 2013). Measurement of the $\delta^{15} \mathrm{~N}_{\text {bulk }}$ values from Woodford Shale samples taken from the Anadarko Basin (Oklahoma) found that there were no trends in $\delta^{15} \mathrm{~N}$ values with thermal maturity, as inferred from vitrinite reflectance measurements (Figure 6A; Rivera et al., 2015). Correlation of the $\delta^{15} \mathrm{~N}_{\text {bulk }}$ values with measured Fe and Mo concentrations once again indicated that the primary control on the $\delta^{15} \mathrm{~N}_{\text {bulk }}$ values appeared be depositional redox conditions (Rivera et al., 2015). Nitrogen isotope analysis of acidified samples from the oil-producing Huron, Three Lick, and Cleveland Shale formations identified variations that corresponded to two distinct depositional environments (Figure 6A; Tuite et al., 2019). Since paleoredox conditions also affect the predominant nitrogen reactions, the identification of these different redox regimes provided information about changing productivity, nutrient cycling, and water column stratification during alternating icehouse/greenhouse conditions (Tuite et al., 2019).

The results from these unconventional petroleum reservoir studies indicate that the sedimentary $\delta^{15} \mathrm{~N}$ values accurately reflect organic matter sources and redox conditions during deposition, which can be used to characterize the unconventional reservoir and evaluate its formation, evolution, and potential hydrocarbon yield. In addition, the $\delta^{15} \mathrm{~N}$ profiles from unconventional reservoir formations can also provide valuable information regarding past biogeochemical cycles, environmental conditions, and climate regimes even though these sediments have undergone significant catagenic alteration (Quan et al., 2013; Rivera et al., 2015; Tuite et al., 2019). This potentially expands the number of locations and geological formations that can be used to address paleoenvironmental and climatic questions, provided that the cores have robust age models and have not been influenced by loss of either organic or inorganic nitrogen phases.

\section{Lacustrine Basins}

Nitrogen reactions and their isotopic signatures are more complex in lacustrine and other freshwater systems due to the influence of terrestrial nutrients and organic matter, the smaller size of the water bodies, and the impacts of seasonal cycles (Talbot 2001 and references within; Quan and Falkowski, 2009 and references within). This means that the use of sedimentary $\delta^{15} \mathrm{~N}$ profiles to interpret paleoenvironmental conditions in lakes is not as well constrained as in marine environments, and evaluation of thermally mature lacustrine formations even less so. As mentioned above, the $\delta^{15} \mathrm{~N}$ values and $\mathrm{C} / \mathrm{N}$ ratios for Type III kerogen and coals do reflect the influence of terrestrial organic material and are distinct from the Type I and Type II kerogen values (Rigby and Batts, 1986; Boudou et al., 2008; Ding et al., 2018; Xie et al., 2021). Analysis of two different lacustrine 
source rocks from the Junggar Basin of China found that crude oils from brackish lacustrine basins were more enriched in pyrrolic-N containing compounds derived from biological sources than crude oils from alkaline lacustrine settings (Zhang et al., 2020). This observed enrichment was attributed to higher terrestrial plant contributions, particularly alkaloid and chlorophyll compounds, to the original organic matter deposits of the brackish lacustrine basin. While changes in $\mathrm{N}$-compounds found in crude oils may also be a consequence of fractionation brought about by migration and thermal maturity, these were not considered to be the main processes responsible for differences in abundance and type of $\mathrm{N}$-containing compounds seen in the end member oils derived from brackish vs. alkaline lacustrine settings (Zhang et al., 2020). Analysis of different organic nitrogen fractions extracted from a single crude oil sample from the Laohe Basin (China) indicated that the polar neutral nitrogen fraction (including pyrrolic-N compounds) was generally enriched in ${ }^{15} \mathrm{~N}$ compared to basic nitrogen compounds by approximately 5\%o (Figure 6B; Oldenburg et al., 2007). While the $\delta^{15} \mathrm{~N}$ values of the crude oils from the Junggar Basin study were not measured, given the differences in organic matter sources and the enrichment of specific pyrrolic- $\mathrm{N}$ compounds, it would not be unexpected for the $\delta^{15} \mathrm{~N}_{\text {oil }}$ values to be significantly different in the brackish basins than the alkaline settings. Oldenburg et al. (2007) attributed the higher $\delta^{15} \mathrm{~N}$ values for pyrrolic- $\mathrm{N}$ compounds to be a result of increasing thermal maturity; however, Zhang et al. (2020) did not find higher concentrations of pyrrolic-N compounds in more mature samples. Resolution of this discrepancy by future studies may provide important information on the relative influence of organic matter source versus thermal maturity in lacustrine and freshwater systems. Given the complexity of processes that could potentially have a significant influence on the $\delta^{15} \mathrm{~N}$ signals in lacustrine systems, it is likely that the processes that impact lacustrine systems will vary depending on geologic setting and history of the particular paleolakes being studied.

\section{Porphyrins}

Porphyrins have traditionally been used as biomarker proxies for thermal maturity and to illustrate different depositional environmental conditions (Mawson et al., 2004). Since porphyrin compounds are direct breakdown products of chloropigments, the $\delta^{15} \mathrm{~N}$ values of porphyrins are considered to be a direct representation of the isotopic composition of those original chloropigments and thus of the original primary producers (e.g., Hayes et al., 1987; Boreham et al., 1989; Boreham et al., 1990; Chicarelli et al., 1993; Kashiyama et al., 2008). Porphyrins have been isolated in petroleum systems in samples with a wide range of maturities and retain the $\delta^{15} \mathrm{~N}$ signal of the original organic matter, so they could be a way to evaluate water column $\mathrm{N}$ reactions during deposition that would not be altered by post-depositional isotopic fractionation processes. Comparison of two different porphyrin fractions, kerogen, and total organic extract isolated from Serpiano oil shale sediments show that porphyrins fractions (average $-3.1 \%$ and $-3.3 \%$ ) are depleted in ${ }^{15} \mathrm{~N}$ relative to the kerogen (average $-0.9 \%$ ) and slightly enriched relative to the total extract (average $-4.0 \%$ )
(Figure 6C; Chicarelli et al., 1993). While the depletion in the porphyrin fractions relative to the kerogen may indicate the influence of an additional nitrogen source, the low $\delta^{15} \mathrm{~N}$ values for all three fractions reflects the influence of predominant $\mathrm{N}_{2}$ fixation to the original organic matter pool (Chicarelli et al., 1993). This indicates that $\delta^{15} \mathrm{~N}_{\text {porphyrin }}$ values can serve to determine whether isotopic fractionation has altered $\delta^{15} \mathrm{~N}_{\text {kerogen }}$ and/or $\delta^{15} \mathrm{~N}_{\text {bulk }}$ values for petroleum systems during catagenesis or migration. While the isolation and measurement of $\delta^{15} \mathrm{~N}$ for porphyrins is not trivial, it may be necessary if post-depositional fractionation processes are suspected and alteration of the $\delta^{15} \mathrm{~N}_{\text {bulk }}$ signal may have occurred.

\section{CONCLUSION AND FUTURE WORK}

In summary, nitrogen isotopes can be a powerful tool in petroleum systems, particularly for evaluating unconventional reservoirs, paleoenvironmental conditions, and organic matter sources. Uncertainties regarding how diagenesis, catagensis, hydrothermal fluids, and hydrocarbon migration processes may have fractionated the initial organic nitrogen deposits can result in significant caveats in terms of interpretation of the $\delta^{15} \mathrm{~N}$ values, and these may limit the use of $\delta^{15} \mathrm{~N}$ profiles as a redox and nitrogen cycle proxy for more complex petroleum systems. The more that is known about non-nitrogen parameters in the petroleum system being analyzed, such as fluid interactions, mineralogy, kerogen type, and porosity and permeability, the more constrained the interpretation of the $\delta^{15} \mathrm{~N}$ measurements can be, and the greater the potential to conclusively identify and characterize paleoenvironmental regimes and biogeochemical cycles. In addition to additional research to better constrain post-depositional nitrogen processes and fractionation, more $\delta^{15} \mathrm{~N}$ data from more locations, wider thermal maturity ranges, and different depositional environments is necessary to link measured $\delta^{15} \mathrm{~N}$ values to specific paleoenvironmental conditions and processes. While caution is advised against placing too much emphasis on specific $\delta^{15} \mathrm{~N}$ values in terms of interpretation, overall trends and excursions present in $\delta^{15} \mathrm{~N}$ profiles from petroleum systems can still provide critical information about reservoir characteristics, particularly depositional paleoredox conditions and organic matter sources.

\section{AUTHOR CONTRIBUTIONS}

All authors listed have made a substantial, direct, and intellectual contribution to the work and approved it for publication.

\section{ACKNOWLEDGMENTS}

The authors would like to thank J. Puckette for his contributions to the section on unconventional reservoirs. This is Oklahoma State University Boone Pickens School of Geology contribution \#2021-123. 


\section{REFERENCES}

Adeboye, O. O., Riedinger, N., Wu, T., Grammer, G. M., and Quan, T. M. (2020). Redox Conditions on the Anadarko Shelf of Oklahoma during the Deposition of the "Mississippian Limestone". Mar. Pet. Geology. 116, 104345. doi:10.1016/ j.marpetgeo.2020.104345

Ader, M., Boudou, J.-P., Javoy, M., Goffe, B., and Daniels, E. (1998). Isotope Study on Organic Nitrogen of Westphalian Anthracites from the Western Middle Field of Pennsylvania (U.S.A.) and from the Bramsche Massif (Germany). Org. Geochem. 29, 315-323. doi:10.1016/s0146-6380(98)00072-2

Ader, M., Cartigny, P., Boudou, J.-P., Oh, J.-H., Petit, E., and Javoy, M. (2006). Nitrogen Isotopic Evolution of Carbonaceous Matter during Metamorphism: Methodology and Preliminary Results. Chem. Geology. 232, 152-169. doi:10.1016/j.chemgeo.2006.02.019

Ader, M., Thomazo, C., Sansjofre, P., Busigny, V., Papineau, D., Laffont, R., et al. (2016). Interpretation of the Nitrogen Isotopic Composition of Precambrian Sedimentary Rocks: Assumptions and Perspectives. Chem. Geology. 429, 93-110. doi:10.1016/j.chemgeo.2016.02.010

Algeo, T. J., Meyers, P. A., Robinson, R. S., Rowe, H., and Jiang, G. Q. (2014). Icehouse-GReenhouse Variations in Marine Denitrification. Biogeosciences. 11, 1273-1295. doi:10.5194/bg-11-1273-2014

Altabet, M. A., and Francois, R. (1994). Sedimentary Nitrogen Isotopic Ratio as a Recorder for Surface Ocean Nitrate Utilization. Glob. Biogeochem. Cycles. 8, 103-116. doi:10.1029/93gb03396

Barth, T., Rist, K., Huseby, B., and Ocampo, R. (1996). The Distribution of Nitrogen Between Bitumen, Water and Residue in Hydrous Pyrolysis of Extracted Messel Oil Shale. Org. Geochem. 24, 889-895. doi:10.1016/s01466380(96)00070-8

Bauersachs, T., Kremer, B., Schouten, S., and Sinninghe Damsté, J. S. (2009). A Biomarker and $\delta 15 \mathrm{~N}$ Study of Thermally Altered Silurian Cyanobacterial Mats. Org. Geochem. 40, 149-157. doi:10.1016/j.orggeochem.2008.11.008

Behar, F., Gillaizeau, B., Derenne, S., and Largeau, C. (2000). Nitrogen Distribution in the Pyrolysis Products of a Type II Kerogen (Cenomanian, Italy). Timing of Molecular Nitrogen Production versus Other Gases. Energy Fuels. 14, 431-440. doi:10.1021/ef990157g

Bokhoven, C., and Theeuwen, H. J. (1966). Determination of the Abundance of Carbon and Nitrogen Isotopes in Dutch Coals and Natural Gas. Nature. 211, 927-929. doi:10.1038/211927a0

Boreham, C. J., Fookes, C. J. R., Popp, B. N., and Hayes, J. M. (1990). Origin of Petroporphyrins. 2. Evidence From Stable Carbon Isotopes. Energy Fuels. 4, 658-661. doi:10.1021/ef00024a007

Boreham, C. J., Fookes, C. J. R., Popp, B. N., and Hayes, J. M. (1989). Origins of Etioporphyrins in Sediments: Evidence From Stable Carbon Isotopes. Geochimica et Cosmochimica Acta. 53, 2451-2455. doi:10.1016/0016-7037(89)90368-2

Boudou, J.-P., Mariotti, A., and Oudin, J.-L. (1984). Unexpected Enrichment of Nitrogen During the Diagenetic Evolution of Sedimentary Organic Matter. Fuel. 63, 1508-1510. doi:10.1016/0016-2361(84)90215-1

Boudou, J.-P., Schimmelmann, A., Ader, M., Mastalerz, M., Sebilo, M., and Gengembre, L. (2008). Organic Nitrogen Chemistry during Low-Grade Metamorphism. Geochimica et Cosmochimica Acta. 72, 1199-1221. doi:10.1016/j.gca.2007.12.004

Brodie, C. R., Heaton, T. H. E., Leng, M. J., Kendrick, C. P., Casford, J. S. L., and Lloyd, J. M. (2011). Evidence for Bias in Measured $\delta 15 \mathrm{~N}$ Values of Terrestrial and Aquatic Organic Materials Due to Pre-analysis Acid Treatment Methods. Rapid Commun. Mass. Spectrom. 25, 1089-1099. doi:10.1002/rcm.4970

Brunner, B., Contreras, S., Lehmann, M. F., Matantseva, O., Rollog, M., Kalvelage, T., et al. (2013). Nitrogen Isotope Effects Induced by Anammox Bacteria. Proc. Natl. Acad. Sci. 110, 18994-18999. doi:10.1073/pnas.1310488110

Calvert, S. E. (2004). Beware Intercepts: Interpreting Compositional Ratios in Multi-Component Sediments and Sedimentary Rocks. Org. Geochem. 35, 981-987. doi:10.1016/j.orggeochem.2004.03.001

Calvert, S. E., Pedersen, T. F., and Karlin, R. E. (2001). Geochemical and Isotopic Evidence for Post-Glacial Palaeoceanographic Changes in Saanich Inlet, British Columbia. Mar. Geology. 174, 278-305. doi:10.1016/s0025-3227(00)00156-0

Charlesworth, J. M. (1986). Interaction of clay Minerals With Organic Nitrogen Compounds Released by Kerogen Pyrolysis. Geochimica et Cosmochimica Acta. 50, 1431-1435. doi:10.1016/0016-7037(86)90316-9
Chen, C., Mei, B., and Cao, Y. (2005). Nitrogen Isotopic Geochemical Characteristics of Crude Oils in Several Basins of China. Sci. China Ser. D-earth Sci. 48, 1211-1219. doi:10.1360/03yd0180

Chicarelli, M. I., Hayes, J. M., Popp, B. N., Eckardt, C. B., and Maxwell, J. R. (1993). Carbon and Nitrogen Isotopic Compositions of Alkyl Porphyrins from the Triassic Serpiano Oil Shale. Geochimica et Cosmochimica Acta. 57, 1307-1311. doi:10.1016/0016-7037(93)90067-7

Compton, J. S., Williams, L. B., and Ferrell, R. E., Jr (1992). Mineralization of Organogenic Ammonium in the Monterey Formation, Santa Maria and San Joaquin Basins, California, USA. Geochimica et Cosmochimica Acta. 56, 1979-1991. doi:10.1016/0016-7037(92)90324-c

Danzelle, J., Riquier, L., Baudin, F., Thomazo, C., and Pucéat, E. (2020). Nitrogen and Carbon Cycle Perturbations Through the Cenomanian-Turonian Oceanic Anoxic Event 2 ( $\sim 94 \mathrm{Ma})$ in the Vocontian Basin (SE France). Palaeogeogr. Palaeoclimatol. Palaeoecol. 538. doi:10.1016/j.palaeo.2019.109443

Delwiche, C. C., and Steyn, P. L. (1970). Nitrogen Isotope Fractionation in Soils and Microbial Reactions. Environ. Sci. Technol. 4, 929-935. doi:10.1021/es60046a004

Ding, D., Liu, G., Fu, B., and Wang, W. (2018). New Insights into the Nitrogen Isotope Compositions in Coals from the Huainan Coalfield, Anhui Province, China: Influence of the Distribution of Nitrogen Forms. Energy Fuels. 32, 9380-9387. doi:10.1021/acs.energyfuels.8b02467

Freudenthal, T., Wagner, T., Wenzhöfer, F., Zabel, M., and Wefer, G. (2001). Early Diagenesis of Organic Matter From Sediments of the Eastern Subtropical Atlantic: Evidence from Stable Nitrogen and Carbon Isotopes. Geochimica et Cosmochimica Acta. 65, 1795-1808. doi:10.1016/s0016-7037(01)00554-3

Froidl, F., Littke, R., Baniasad, A., Zheng, T., Röth, J., Böcker, J., et al. (2021). Peculiar Berriasian "Wealden" Shales of Northwest Germany: Organic Facies, Depositional Environment, Thermal Maturity and Kinetics of Petroleum Generation. Mar. Pet. Geology. 124, 104819. doi:10.1016/ j.marpetgeo.2020.104819

Ganeshram, R. S., Pedersen, T. F., Calvert, S. E., and Murray, J. W. (1995). Large Changes in Oceanic Nutrient Inventories From Glacial to Interglacial Periods. Nature. 376, 755-758. doi:10.1038/376755a0

Gillaizeau, B., Behar, F., Derenne, S., and Largeau, C. (1997). Nitrogen Fate During Laboratory Maturation of a Type I Kerogen (Oligocene, Turkey) and Related Algaenan: Nitrogen Mass Balances and Timing of N2 Production versus Other Gases. Energy Fuels. 11, 1237-1249. doi:10.1021/ef970060z

Godfrey, L. V., and Falkowski, P. G. (2009). Nitrogen, its Cycle and Redox State in the Late Archaean Ocean. Nat. Geosci. 2, 725-729. doi:10.1038/ngeo633

Hayes, J. M., Takigiku, R., Ocampo, R., Callot, H. J., and Albrecht, P. (1987). Isotopic Compositions and Probable Origins of Organic Molecules in the Eocene Messel Shale. Nature. 329, 48-51. doi:10.1038/329048a0

Hedges, J. I., and Mann, D. C. (1979). The Characterization of Plant Tissues by Their Lignin Oxidation Products. Geochimica et Cosmochimica Acta. 43, 1803-1807. doi:10.1016/0016-7037(79)90028-0

Higgins, M. B., Robinson, R. S., Carter, S. J., and Pearson, A. (2010). Evidence From Chlorin Nitrogen Isotopes for Alternating Nutrient Regimes in the Eastern Mediterranean Sea. Earth Planet. Sci. Lett. 290, 102-107. doi:10.1016/ j.epsl.2009.12.009

Higgins, M. B., Robinson, R. S., Husson, J. M., Carter, S. J., and Pearson, A. (2012). Dominant Eukaryotic export Production during Ocean Anoxic Events Reflects the Importance of Recycled NH4+. Proc. Natl. Acad. Sci. 109, 2269-2274. doi:10.1073/pnas.1104313109

Hoefs, J. (2004). Stable Isotope Geochemistry. Berlin Heidelberg: Springer-Verlag. doi:10.1007/978-3-662-05406-2

Hoering, T. C., and Moore, H. E. (1958). The Isotopic Composition of the Nitrogen in Natural Gases and Associated Crude Oils. Geochimica et Cosmochimica Acta. 13, 225-232. doi:10.1016/0016-7037(58)90024-3

Holloway, J. M., and Dahlgren, R. A. (2002). Nitrogen in Rock: Occurrences and Biogeochemical Implications. Glob. Biogeochem. Cycles. 16, 65-71. doi:10.1029/ 2002GB001862

Holmes, M. E., Eichner, C., Struck, U., Wefer, G., Fischer, G., and Wefer, G. (1999). "Reconstruction of Surface Ocean Nitrate Utilization Using Stable Nitrogen Isotopes in Sinking Particles and Sediments," in The Use of Proxies in Paleoceanography: Examples from the South Atlantic (Springer), 447-468. doi:10.1007/978-3-642-58646-0 18

Jenkyns, H. C., Gröcke, D. R., and Hesselbo, S. P. (2001). Nitrogen Isotope Evidence for Water Mass Denitrification During the Early Toarcian 
(Jurassic) Oceanic Anoxic Event. Paleoceanography. 16, 593-603. doi:10.1029/ 2000pa000558

Kashiyama, Y., Ogawa, N. O., Shiro, M., Tada, R., Kitazato, H., and Ohkouchi, N. (2008). Reconstruction of the Biogeochemistry and Ecology of Photoautotrophs Based on the Nitrogen and Carbon Isotopic Compositions of Vanadyl Porphyrins from Miocene Siliceous Sediments. Biogeosciences. 5, 797-816. doi:10.5194/bg-5-797-2008

Kendall, C., and Caldwell, E. A. (1998). Fundamentals of Isotope Geochemistry in Isotope Tracers in Catchment Hydrology. Editors C. Kendall and J. J. McDonnell (Amsterdam: Elsevier Science B.V), 51-86. doi:10.1016/b978-0-444-81546$0.50009-4$

Kendall, C. (1998). Tracing Nitrogen Sources and Cycling in Catchments in Isotope Tracers in Catchment Hydrology. Editors C. Kendall and J. J. McDonnell (Amsterdam: Elsevier Science B.V), 519-576. doi:10.1016/b978-0-444-815460.50023-9

Kotarba, M. J., Bilkiewicz, E., and Kosakowski, P. (2020). Origin of Hydrocarbon and Non-Hydrocarbon (H2S, CO2 and N2) Components of Natural Gas Accumulated in the Zechstein Main Dolomite Carbonate Reservoir of the Western Part of the Polish Sector of the Southern Permian Basin. Chem. Geology. 554, 119807. doi:10.1016/j.chemgeo.2020.119807

Krooss, B. M., Friberg, L., Gensterblum, Y., Hollenstein, J., Prinz, D., and Littke, R. (2005). Investigation of the Pyrolytic Liberation of Molecular Nitrogen from Palaeozoic Sedimentary Rocks. Int. J. Earth Sci. (Geol Rundsch). 94, 1023-1038. doi:10.1007/s00531-005-0012-3

Krooss, B. M., Littke, R., Müller, B., Frielingsdorf, J., Schwochau, K., and Idiz, E. F. (1995). Generation of Nitrogen and Methane from Sedimentary Organic Matter: Implications on the Dynamics of Natural Gas Accumulations. Chem. Geology. 126, 291-318. doi:10.1016/0009-2541(95)00124-7

Lee, C., Love, G. D., Hopkins, M. J., Kröger, B., Franeck, F., and Finnegan, S. (2019). Lipid Biomarker and Stable Isotopic Profiles through Early-Middle Ordovician Carbonates From Spitsbergen, Norway. Org. Geochem. 131, 5-18. doi:10.1016/ j.orggeochem.2019.02.008

Lehmann, M. F., Bernasconi, S. M., Barbieri, A., and McKenzie, J. A. (2002). Preservation of Organic Matter and Alteration of its Carbon and Nitrogen Isotope Composition During Simulated and In Situ Early Sedimentary Diagenesis. Geochimica et Cosmochimica Acta. 66, 3573-3584. doi:10.1016/ s0016-7037(02)00968-7

Littke, R., Krooss, B., Idiz, E., and Frielingsdorf, J. (1995). Molecular Nitrogen in Natural-Gas Accumulations - Generation From Sedimentary Organic-Matter at High-Temperatures. Am. Assoc. Pet. Geologists Bull. 79, 410-430. doi:10.1306/8D2B1548-171E-11D7-8645000102C1865D

Macko, S. A., and Estep, M. L. F. (1984). Microbial Alteration of Stable Nitrogen and Carbon Isotopic Compositions of Organic Matter. Org. Geochem. 6, 787-790. doi:10.1016/0146-6380(84)90100-1

Mawson, D. H., Walker, J. S., and Keely, B. J. (2004). Variations in the Distributions of Sedimentary Alkyl Porphyrins in the Mulhouse Basin in Response to Changing Environmental Conditions. Org. Geochem. 35, 1229-1241. doi:10.1016/j.orggeochem.2004.05.007

Meyers, P. A., Yum, J.-G., and Wise, S. W. (2009). Origins and Maturity of Organic Matter in Mid-Cretaceous Black Shales From ODP Site 1138 on the Kerguelen Plateau. Mar. Pet. Geology. 26, 909-915. doi:10.1016/j.marpetgeo.2008.09.003

Oldenburg, T. B. P., Larter, S. R., and Huang, H. (2007). Nitrogen Isotope Systematics of Petroleum Fractions of Differing Polarity - Neutral versus Basic Compounds. Org. Geochem. 38, 1789-1794. doi:10.1016/j.orggeochem.2007.05.016

Peters, K. E., Rohrback, B. G., and Kaplan, I. R. (1981). Geochemistry of Artificially Heated Humic and Sapropelic Sediments-I: Protokerogen. AAPG Bull. 65, 688-705. doi:10.4319/lo.1978.23.4.0598।

Peters, K. E., Sweeney, R. E., and Kaplan, I. R. (1978). Correlation of Carbon and Nitrogen Stable Isotope Ratios in Sedimentary Organic Matter. Limnol. Oceanogr. 23, 598-604. doi:10.4319/lo.1978.23.4.0598

Prokopenko, M., Hammond, D., Berelson, W., Bernhard, J., Stott, L., and Douglas, R. (2006). Nitrogen Cycling in the Sediments of Santa Barbara basin and Eastern Subtropical North Pacific: Nitrogen Isotopes, Diagenesis and Possible Chemosymbiosis Between Two Lithotrophs (Thioploca and Anammox)"riding on a Glider". Earth Planet. Sci. Lett. 242, 186-204. doi:10.1016/ j.epsl.2005.11.044

Quan, T. M., Adigwe, E. N., Riedinger, N., and Puckette, J. (2013). Evaluating Nitrogen Isotopes as Proxies for Depositional Environmental Conditions in
Shales: Comparing Caney and Woodford Shales in the Arkoma Basin, Oklahoma. Chem. Geology. 360-361, 231-240. doi:10.1016/j.chemgeo.2013.10.017

Quan, T. M., and Falkowski, P. G. (2009). Redox Control of N:P Ratios in Aquatic Ecosystems. Geobiology. 7, 124-139. doi:10.1111/j.1472-4669.2008.00182.x

Quan, T. M., van de Schootbrugge, B., Field, M. P., Rosenthal, Y., and Falkowski, P. G. (2008). Nitrogen Isotope and Trace Metal Analyses from the Mingolsheim Core (Germany): Evidence for Redox Variations across the Triassic-Jurassic Boundary. Glob. Biogeochem. Cycles. 22, a-n. doi:10.1029/2007gb002981

Rigby, D., and Batts, B. D. (1986). The Isotopic Composition of Nitrogen in Australian Coals and Oil Shales. Chem. Geology. Isotope Geosci. section. 58, 273-282. doi:10.1016/0168-9622(86)90016-3

Rivera, K. T., Puckette, J., and Quan, T. M. (2015). Evaluation of Redox Versus thermal Maturity Controls on $\delta 15 \mathrm{~N}$ in Organic Rich Shales: A Case Study of the Woodford Shale, Anadarko Basin, Oklahoma, USA. Org. Geochem. 83-84, 127-139. doi:10.1016/j.orggeochem.2015.03.005

Robinson, R. S., Kienast, M., Luiza Albuquerque, A., Altabet, M., Contreras, S., De Pol Holz, R., et al. (2012). A Review of Nitrogen Isotopic Alteration in Marine Sediments. Paleoceanography. 27, PA4203. doi:10.1029/2012pa002321

Ryabenko, E., Kock, A., Bange, H. W., Altabet, M. A., and Wallace, D. W. R. (2012). Contrasting Biogeochemistry of Nitrogen in the Atlantic and Pacific Oxygen Minimum Zones. Biogeosciences 9, 203-215. doi:10.5194/bg-9-203-2012

Schimmelmann, A., and Lis, G. P. (2010). Nitrogen Isotopic Exchange During Maturation of Organic Matter. Org. Geochem. 41, 63-70. doi:10.1016/j.orggeochem.2009.01.005 Scholten, S. O. (1991). The Distribution of Nitrogen Isotopes in Sediments. Utrecht, Netherlands: PhD, University of Utrecht. doi:10.1142/9789814539166

Sigman, D. M., and Casciotti, K. L. (2001). Nitrogen Isotopes in the Ocean, in Encyclopedia of Ocean Sciences. Editors J. H. Steele, K. K. Turekain, and S. A. Thorpe (San Diego, CA: Academic Press), 1884-1894. doi:10.1006/ rwos.2001.0172

Stiehl, G., and Lehmann, M. (1980). Isotopenvariationen des Stickstoffs Humoser und Bituminöser Natürlicher Organischer Substanzen. Geochimica et Cosmochimica Acta. 44, 1737-1746. doi:10.1016/0016-7037(80)90224-0

Stüeken, E. E., Zaloumis, J., Meixnerová, J., and Buick, R. (2017). Differential Metamorphic Effects on Nitrogen Isotopes in Kerogen Extracts and Bulk Rocks. Geochimica et Cosmochimica Acta. 217, 80-94. doi:10.1016/j.gca.2017.08.019

Talbot, M. R. (2001). "Nitrogen Isotopes in Palaeolimnology in Tracking Environmental Change Using Lake Sediments," in Physical and Geochemical Methods. 2. Editors W. M. Last and J. P. Smol (Dordrecht, Netherlands: Kluwer Academic Publishers), Vol. 2, 401-439.

Tissot, B. P., and Welte, D. H. (1984). Petroleum Formation and Occurance. Berlin: Springer-Verlag. doi:10.1007/978-3-642-87813-8

Tuite, M. L., Jr., Williford, K. H., and Macko, S. A. (2019). From Greenhouse to Icehouse: Nitrogen Biogeochemistry of an Epeiric Sea in the Context of the Oxygenation of the Late Devonian Atmosphere/ocean System. Palaeogeogr. Palaeoclimatol. Palaeoecol. 531, 109204. doi:10.1016/j.palaeo.2019.05.026

Vandenbrouke, M., and Largeau, C. (2007). Kerogen Origin, Evolution and Structure. Org. Geochem. 38, 719-833. doi:10.1016/j.orggeochem.2007.01.001

Wada, E., Goldberg, E. D., and Tokyo, Y. H. (1980). Nitrogen Isotope Fractionation and its Significance in Biogeochemical Processes Occuring in Marine Environments in Isotope Marine Chemistry. Uchida Rokakuho Publ. Co. Ltd., 375-398.

Wada, E., Kadonaga, T., and Matsuo, S. (1975). ${ }^{15} \mathrm{~N}$ Aboundance in Nitrogen of Naturally Occurring Substances and Global Assessment of Denitrification from Isotopic Viewpoint. Geochem. J. 9, 139-148. doi:10.2343/geochemj.9.139

Whiticar, M. J. (1996). Stable Isotope Geochemistry of Coals, Humic Kerogens and Related Natural Gases. Int. J. Coal Geology. 32, 191-215. doi:10.1016/s01665162(96)00042-0

Williams, L. B., Ferrell, R. E., Hutcheon, I., Bakel, A. J., Walsh, M. M., and Krouse, H. R. (1995). Nitrogen Isotope Geochemistry of Organic Matter and Minerals during Diagenesis and Hydrocarbon Migration. Geochimica et Cosmochimica Acta. 59, 765-779. doi:10.1016/0016-7037(95)00005-k

Xie, P., Dai, S., Hower, J. C., Nechaev, V. P., French, D., Graham, I. T., et al. (2021). Nitrogen Isotopic Compositions in $\mathrm{NH}_{4}{ }^{+}$-mineral-bearing Coal: Origin and Isotope Fractionation. Chem. Geology. 559. doi:10.1016/ j.chemgeo.2020.119946

Zhang, J., Cao, J., Xia, L., Xiang, B., and Li, E. (2020). Investigating Biological Nitrogen Cycling in Lacustrine Systems by FT-ICR-MS Analysis of NitrogenContaining Compounds in Petroleum. Palaeogeogr. Palaeoclimatol. Palaeoecol. 556, 109887. doi:10.1016/j.palaeo.2020.109887 
Zhu, Y., Shi, B., and Fang, C. (2000). The Isotopic Compositions of Molecular Nitrogen: Implications on Their Origins in Natural Gas Accumulations. Chem. Geology. 164, 321-330. doi:10.1016/s0009-2541(99)00151-5

Conflict of Interest: The authors declare that the research was conducted in the absence of any commercial or financial relationships that could be construed as a potential conflict of interest.

Publisher's Note: All claims expressed in this article are solely those of the authors and do not necessarily represent those of their affiliated organizations, or those of the publisher, the editors and the reviewers. Any product that may be evaluated in this article, or claim that may be made by its manufacturer, is not guaranteed or endorsed by the publisher.

Copyright (C) 2021 Quan and Adeboye. This is an open-access article distributed under the terms of the Creative Commons Attribution License (CC BY). The use, distribution or reproduction in other forums is permitted, provided the original author(s) and the copyright owner(s) are credited and that the original publication in this journal is cited, in accordance with accepted academic practice. No use, distribution or reproduction is permitted which does not comply with these terms. 